\title{
Sistem Klasifikasi Tingkat Keparahan Retinopati Diabetik Menggunakan Support Vector Machine
}

\author{
Taufiq Galang Adi Putranto*1, Ika Candradewi ${ }^{2}$ \\ ${ }^{1}$ Prodi Elektronika dan Instrumentasi, DIKE, FMIPA, UGM, Yogyakarta, Indonesia \\ ${ }^{2}$ Department of Computer Science and Electronics, FMIPA UGM, Yogyakarta, Indonesia \\ email: ${ }^{* 1}$ taufiqgalang@gmail.com, ${ }^{2}$ ika.candradewi@ugm.ac.id
}

\begin{abstract}
Abstrak
Retinopati diabetik merupakan suatu penyakit gangguan penglihatan yang dapat menyebabkan kerusakan pada bagian retina mata yang berdampak langsung pada terganggunya penglihatan penderita. Penyakit retinopati diabetit diklasifikasikan menjadi empat fase (normal, mild NPDR (Non-Proliferative Diabetic Retinopathy), moderate NPDR, severe NPDR). Dengan menerapkan pengolahan citra, gambar retina mata di ekstraksi menggunakan ekstraksi ciri area hasil deteksi eksudat, pembuluh darah, mikroaneurisma, dan ekstraksi ciri tekstur Gray Level Co-occurrence Matrix. Hasil fitur ekstraksi yang didapat kemudian diklasifikasikan menggunakan metode Support Vector Machine dengan kernel Radial Basis Function (RBF). Klasifikasi dievaluasi dengan parameter: Akurasi (accuracy), Kekhususan (specificity), dan Sensitivitas (sensitivity).

Hasil klasifikasi menunjukan nilai terbaik dengan menggunakan 6 ciri statistik antara lain, contrast, homogeneity, correlation, energy, entropy dan inverse difference moment pada arah 45 derajat dengan kernel RBF. Hasil penelitian klasifikasi sistem pada 240 data training dan 60 data testing menghasilkan nilai rata-rata akurasi sebesar 95,93\%, nilai specificity sebesar 97,29\%, dan nilai sensitivity sebesar 91,07\%. Dilihat dari hasil penelitian, kernel RBF menghasilkan akurasi terbaik jika dibandingkan dengan kernel polynomial atau kernel linear
\end{abstract}

Kata kunci - Retinopati diabetik, gray level co-occurrence matrix, ciri area, support vector machine.

\begin{abstract}
Absract
Diabetic retinopathy is a vision disorder disease that can cause damage to the retina of the eye that will have a direct impact on the disruption of vision of the patient. The diabetic retinopathy phase is classified into four types (normal, mild NPDR, moderate NPDR (NonProliferative Diabetic Retinopathy), and severe NPDR). Retinal of eye data of diabetic retinopathy patients treated from the MESSIDOR database. By applying image processing, the retinal image of the eye in extraction using the area features extraction from the detection of exudate, blood vessels, microaneurysms, and texture feature extraction Gray Level Cooccurrence Matrix. The extracted results classified using the Support Vector Machine method with the Radial Basis Function (RBF) kernel. Classification evaluated with these parameters: Accuracy, specificity, and sensitivity.

The results of classification show the best value using 6 statistical features ie, contrast, homogeneity, correlation, energy, entropy and inverse difference moment in the direction of 45 degrees with the RBF kernel. The result of classification research system on 240 data training and 60 data testing yields an average accuracy is $95.93 \%$, the value of specificity is $97.29 \%$, and a sensitivity rating is $91.07 \%$. From the research result, using RBF kernel get the best accuracy result than using kernel polynomial or kernel linear
\end{abstract}

Keywords-Diabetic retinopathy, gray level co-occurrence matrix, area feature, support vector machine.

Received December 12 ${ }^{\text {th }}, 2017$; Revised March 23 ${ }^{\text {th }}, 2018$; Accepted April $29^{\text {th }}, 2018$ 


\section{PENDAHULUAN}

Diabetes atau disebut sebagai penyakit kencing manis merupakan penyakit yang terjadi karena pancreas tidak sanggup menghasilkan cukup insulin. Penderita penyakit diabetes dalam waktu yang lama memiliki resiko terhadap berbagai kelainan seperti hipoglikemia, ketoasidasis, dan komplikasi. Dampak yang cukup membahayakan adalah komplikasi, komplikasi dibagi menjadi dua yaitu komplikasi makrovaskular dan komplikasi mikrovaskular. Komplikasi makrovaskular menyebabkan terjadinya penyumbatan pada pembuluh darah besar seperti pada jantung dan otak. Sedangkan komplikasi mikrovaskular menyebabkan penyumbatan pembuluh darah kecil seperti di ginjal dan mata yang dapat mengakibatkan penderita mengalami gangguan penglihatan bahkan kebutaan [1].

Komplikasi jangka panjang yang dialami pada penderita diabetes yaitu retinopati dengan potensi kehilangan penglihatan, neufropati yang menyebabkan gagal ginjal, dan neuropati dengan memiliki resiko ulkus kaki dan mennyebabkan kaki harus di amputasi. Resiko menderita retinopati diabetik meningkat sebanding dengan semakin lamanya seseorang menyandang diabetes mellitus [2]. Non-Proliferatif Diabetic Retinopathy (NPDR) atau tahap awal yang lebih ringan pada penderita retinopati diabetik dan memiliki tiga tingkatan tersendiri pada kelas retinopati NPDR. Retinopati diabetik dibagi menjadi empat fase (normal, mild NPDR, moderate NPDR, severe NPDR) menurut The Early Treatment of Diabetic Retinopathy Study (ETDRS) [3].

Beberapa peneliti mengidentifikasi dan klasifikasi fase retinopati diabetik menggunakan segmentasi dengan berbagai metode pengolahan citra berbasis warna dan tekstur. Mengacu pada penelitian sebelumnya maka penulis melakukan penelitian sistem klasifikasi retinopati diabetik menggunakan ekstraksi ciri area dan ekstraksi ciri Gray Level Co-occurrence Matrix serta metode klasifikasi support vector machine untuk menunjang klasifikasi pembeda 4 fase retinopati diabetik (normal, mild NPDR, moderate NPDR, severe NPDR).

\section{METODE PENELITIAN}

\subsection{Analisis Sistem}

Rancangan sistem secara perangkat lunak (software) dengan pengolahan citra berdasarkan library MATLAB. Perancangan sistem ini pada proses ekstraksi ciri menggabungkan hasil ekstraksi ciri area dan ekstraksi ciri tekstur dengan metode Gray Level Co-occurrence. Pada tahap klasifikasi menggunakan metode support vector machine dengan kernel Radial Basis Function (RBF). Data citra yang di ambil cirinya dengan ekstraksi ciri area dan ekstraksi ciri tekstur Gray Level Co-occurrence Matrix serta di klasifikasikan menggunakan Support Vector Machine (SVM) berupa empat fase retinopati diabetik yaitu fase normal, fase mild NPDR, fase moderate NPDR, dan fase severe NPDR. Secara keseluruhan, blok diagram sistem dapat dilihat pada Gambar 1.

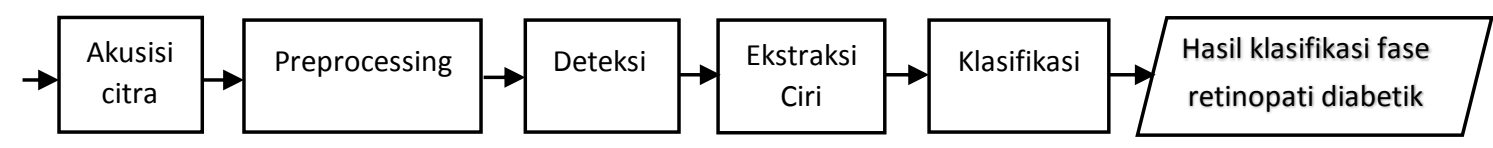

Gambar 1. Diagram blok sistem kesuluruhan

Pada blok diagram sistem Gambar 1 didapatkan alur sistem yaitu pertama citra retina yang di identifikasi akan dilakukan pengubahan ukuran citra untuk mempercepat proses komputasi. Citra retina mata kemudian masuk pada tahap preprocessing dan deteksi dengan mendeteksi eksudat, mikroaneurisma, dan pembuluh darah yang merupakan beberapa tanda yang muncul pada penderita retinopati diabetik [4]. Setelah proses deteksi selesai kemudian hasil deteksi tersebut di lakukan ekstraksi ciri area yang digabungkan dengan hasil ekstraksi ciri tekstur Gray Level Co-occurrence Matrix pada citra grayscale retina. Kemudian dilanjutkan ke

IJEIS Vol. 8, No. 1, April 2018: 37-48 
tahap klasifikasi fase retinopati diabetik menjadi empat fase, karena sistem ini dirancang untuk mengklasifikasi menjadi empat jenis (normal, mild NPDR, moderate NPDR, severe NPDR) maka menggunakan metode non-linear Support Vector Machine (SVM). Metode klasifikasi SVM non-linear menggunakan multiclass merupakan sistem untuk mengklasifikasikan lebih dari dua jenis. Karena penelitian ini di fokuskan untuk mengklasifikasikan fase retinopati diabetik, maka digunakan ekstraksi ciri dan klasifikasi ke dalam empat fase retinopati diabetik. Data yang diperoleh dari ekstraksi ciri terbagi manjadi empat fase yang kemudian dipisahkan oleh garisklasifikasi (Hyperplane).

\subsection{Rancangan Arsitektur Sistem}

Pada rancangan aristekstur keseluruhansistem, citra masukan akan mengalami beberapa proses preprocessing untuk melakukan ekstrak ciri area dari citra hasil proses deteksi dan ekstraksi ciri GLCM. Proses deteksi melakukan deteksi tanda-tanda yang muncul pada retina mata penderita retinopati diabetik seperti eksudat, mikroaneurisma, dan pembuluh darah. Gambar 2 merupakan bagan arsitektur keseluruhan sistem yang terjadi pada penelitian ini.

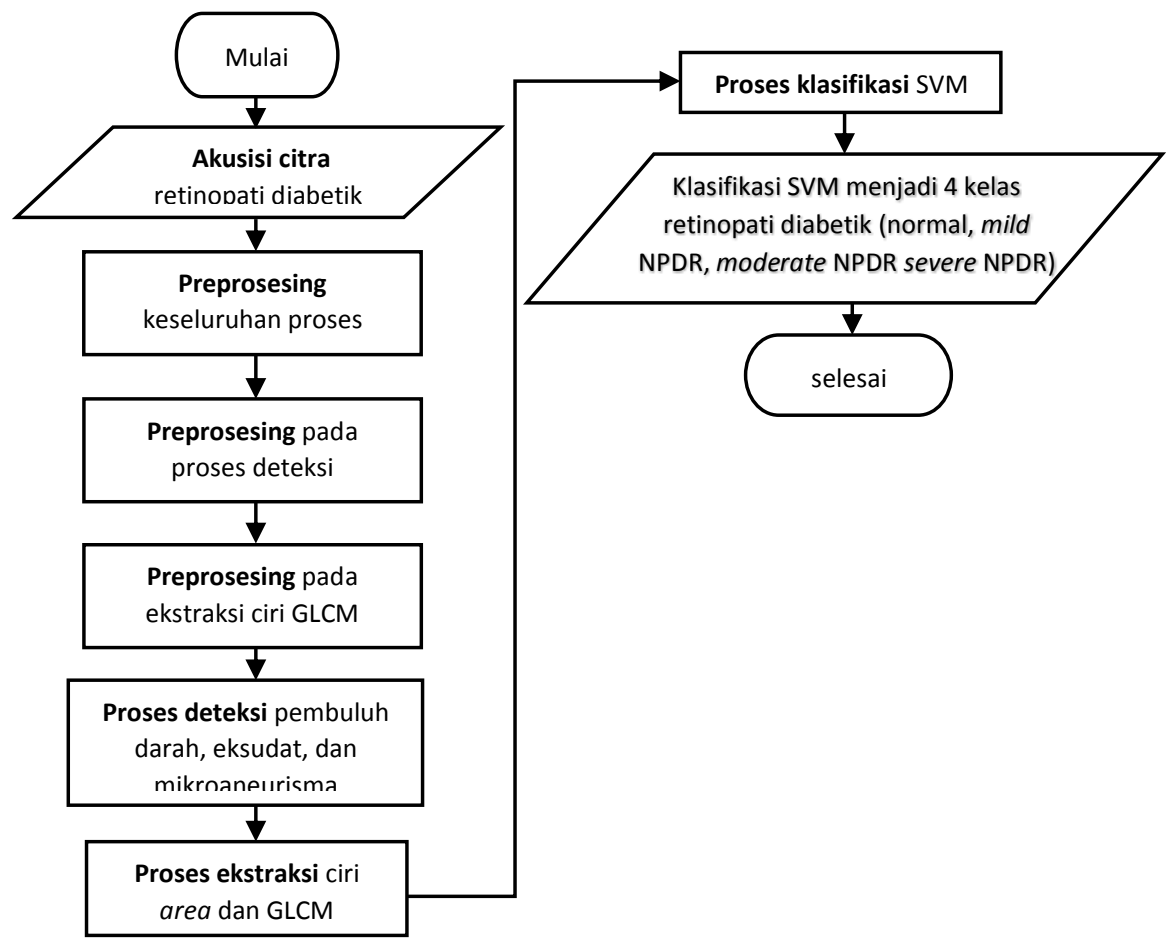

Gambar 2 Daigram alir rancangan arsitektur keseluruhan sistem

Setelah sistem deteksi menyimpan citra hasil deteksinya maka tahap selanjutnya adalah tahap ekstraksi ciri. Sistem klasifikasi dibagi menjadi empat proses utama yaitu akusisi citra, preprocessing, ekstraksi ciri, dan klasifikasi.

\subsection{Rancangan Sistem Deteksi}

Pada penelitian ini tahap deteksi terbagi menjadi beberapa proses deteksi seperti deteksi yang digunakan untuk menghilangkan objek yang tidak di inginkan dan proses deteksi yang bertujuan untuk mendapatkan tanda yang muncul pada penderita retinopati diabetik dalam bentuk citra biner. Langkah pertama yang digunakan pada tahap deteksi adalah melakukan preprocessing pada citra retina masukan. Citra yang masuk terlebih dahulu di ubah ukurannya untuk mempersingkat waktu komputasi dan melakukan cropping agar lebih terfokus pada citra retina yang akan diolah. Masing-masing proses deteksi memiliki tahap preprocessing yang berbeda seperti yang ditunjukan pada Gambar 3. Pada proses preprocessing terdapat tahap perbaikan citra menggunakan CLAHE (Contrast Limited Adapive Histogram Equalization) yang merupakan modifikasi dari AHE (Adaptive Histogram Thresholding). Citra yang diproses 
menggunakan CLAHE dibagi menjadi beberapa blok kemudian meningkatkan kontras tiap blok, sehingga daerah histogram yang diproses kira-kira sesuai dengan histogram yang ditentukan oleh distribusi yang mungkin merupakan binominal, gaussian, poisson atau Rayleigh [5]

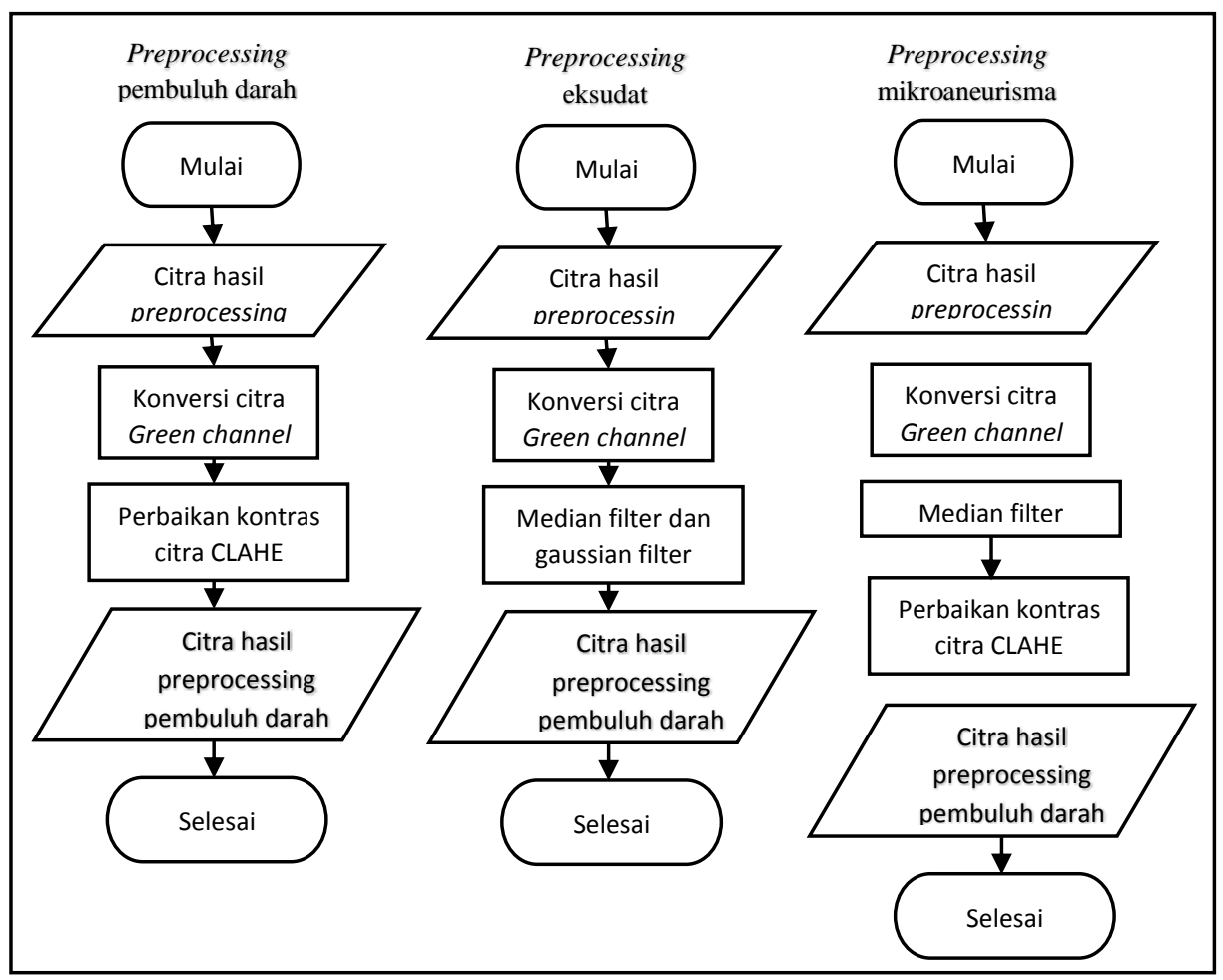

Gambar 3 Tahap preprocessing citra pada setiap proses deteksi

Proses deteksi yang digunakan untuk menghilangkan objek yang tidak di inginkan terdiri dari deteksi garis tepi citra retina dan deteksi optical disc. Kedua objek tersebut butuh di eliminasi dikarenakan dapat mengakibatkan kesalahan pada proses deteksi yang berdampak pada hasil klasifikasi. Pada Gambar 4 merupakan proses deteksi garis tepi citra retina.

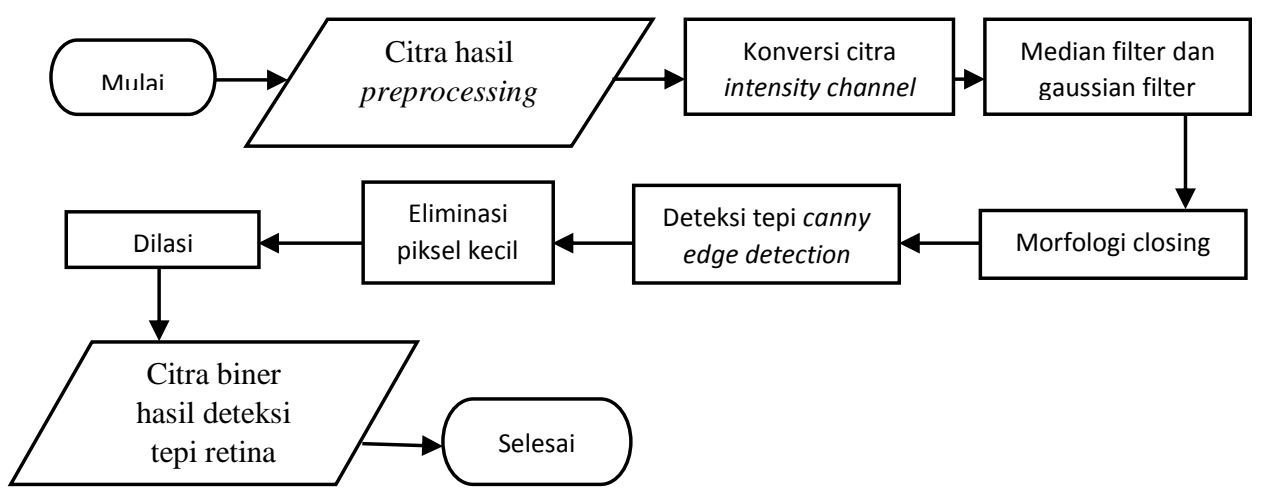

Gambar 4 Diagram alir proses deteksi garis tepi citra retina

Citra masukan melalui tahap preprocessing dan kemudian dilanjutkan pada tahap segmentasi citra yaitu morfologi closing dan canny edge detection. Deteksi tepi canny dipilih karena dapat mendeteksi dengan baik sehingga dapat melakukan pemilihan parameter untuk menandai semua tepi sehingga dapat menghasilkan jarak minimum antara tepi yang dideteksi dengan tepi yang asli [6]. Morfologi closing membuat citra menjadi lebih buram sehingga ketika dilakukan deteksi tepi dengan canny edge detection hanya menghasilkan garis tepi citra retina. 
Proses deteksi objek yang tidak di inginkan yang kedua adalah deteksi optical disc. Tahap deteksi optical disc dapat dilihat pada Gambar 5.

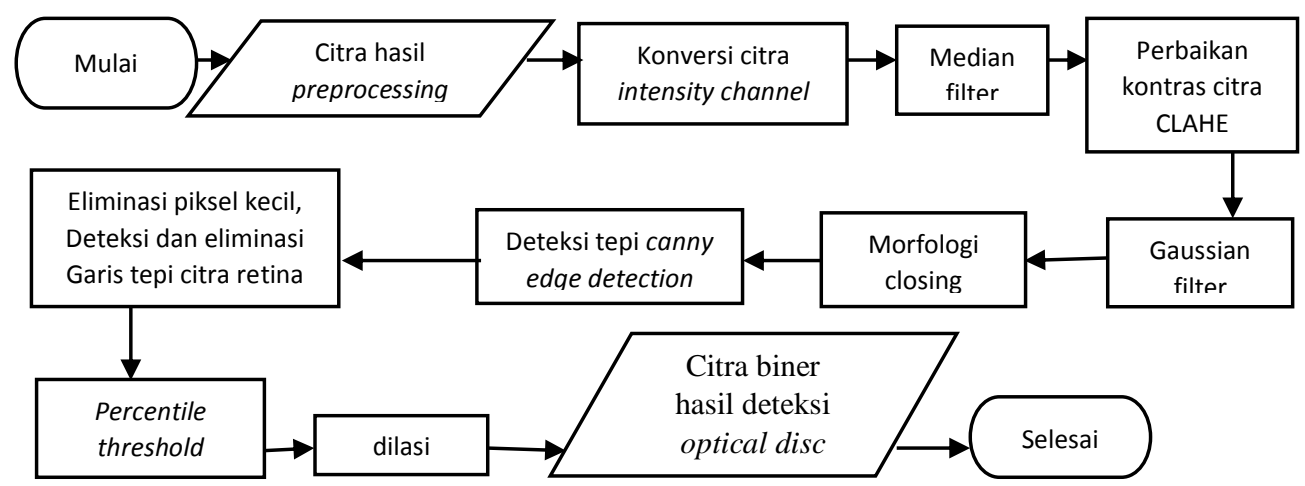

Gambar 5 Diagram alir proses deteksi optical disc

Pada proses deteksi optical disc mempunyai tahap segmentasi yang sama dengan proses deteksi garis tepi citra retina. perbedaan diantara keduanya terletak pada ukuran structur element yang digunakan saat proses morfologi closing dan nilai threshold pada canny edge detection. Tahapan threshold dengan percentile threshold digunakan menjadikan wilayah paling terang pada citra bernilai 1 atau white pixel dan yang lain bernilai 0 atau black pixel.

Proses deteksi selanjutnya adalah mendeteksi tanda yang muncul pada penderita retinopati diabetik. Tanda pertama yang di deteksi adalah pembuluh darah. Pembuluh darah semakin bercabang sebanding dengan meningkatnya kelas retinopati diabetik. Proses deteksi pembuluh darah ditunjukan pada Gambar 6

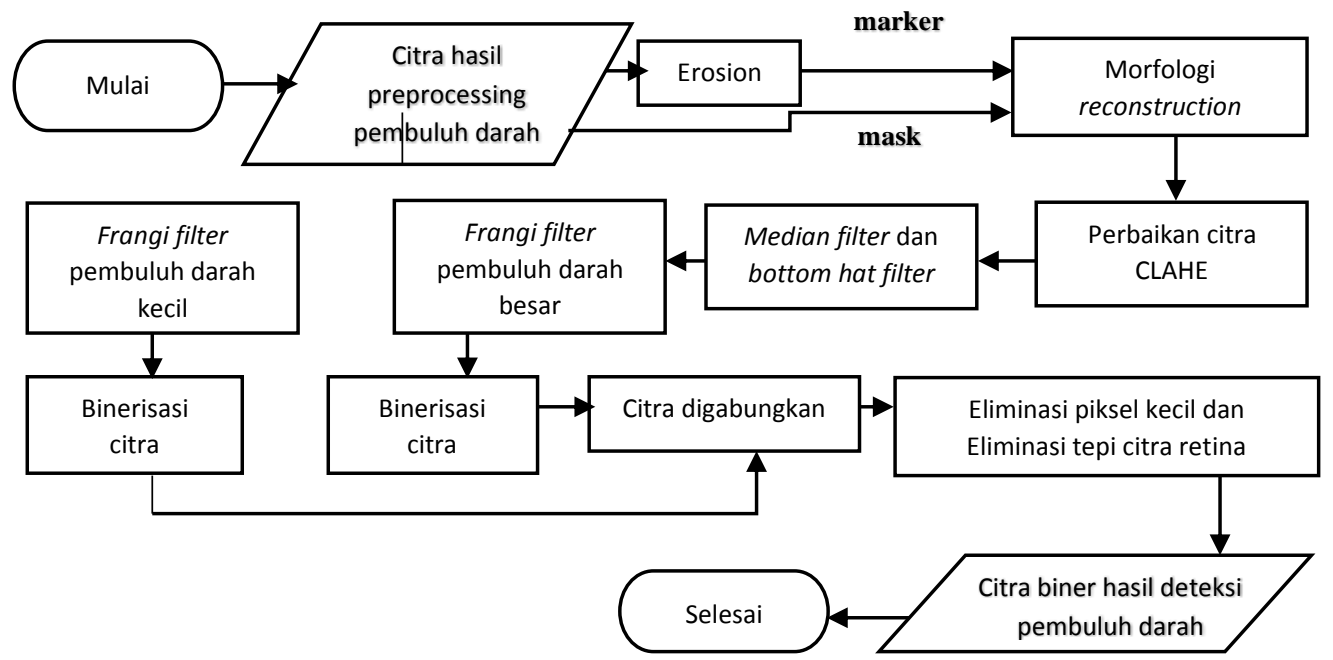

Gambar 6 Diagram alir proses deteksi pembuluh darah

Pada proses deteksi pembuluh darah langkah pertama yang dilakukan melakukan segmentasi citra menggunakan morfologi reconstruction dengan menjadikan citra hasil preprocessing sebagai mask dan citra hasil erosi sebagai marker. Citra deteksi pembuluh darah akan diperjelas menggunakan frangi filter dengan nilai gamma yang berbeda dapat digunakan untuk mendapatkan pembuluh darah kecil dan besar. Frangi filter yang telah disempurnakan dapat secara efektif mengurangi jumlah stuktur pembuluh palsu dan noise yang terisolasi dalam proses penyempurnaan pembuluh darah [7].

Proses deteksi selanjutnya adalah deteksi eksudat. Eksudat muncul pada retina mata penderita retinopati diabetik. Semaki parahnya fase retinopati dibetik semakin meningkat pula jumlah eksudat yang terdapat pada retina mata. Eksudat merupakan infiltrasi lipid ke dalam 
retina mempunyai bentuk tidak beraturan dan berwarna kekuningan. Pada proses deteksi eksudat dapat dilihat pada Gambar 7.

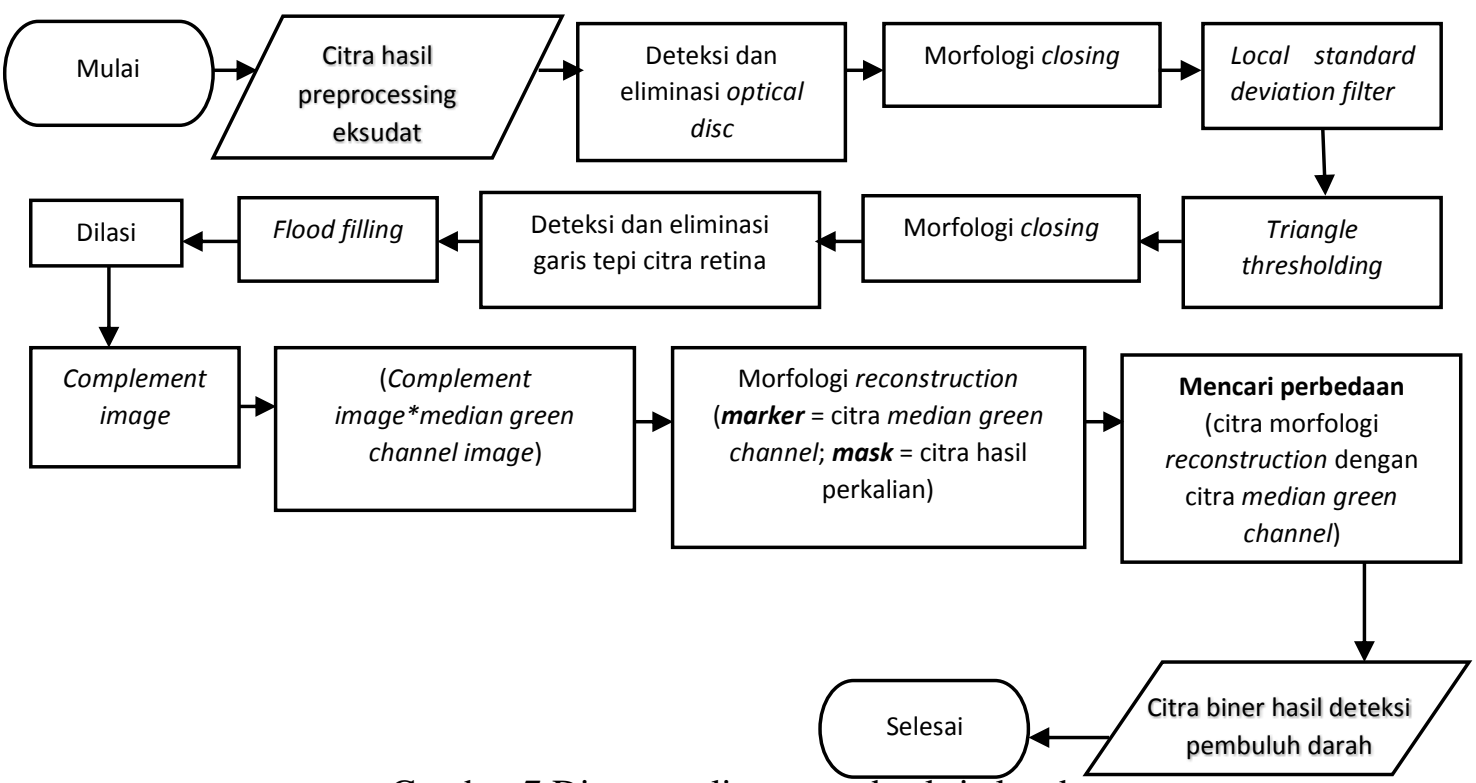

Gambar 7 Diagram alir proses deteksi eksudat

Mikroanurisma merupakan salah satu tanda yang muncul pada pendertita retinopati diabetik. mikroaneurisma merupakan penonjolan dinding kapiler terutama daerah vena dengan bentuk berupa bintik merah kecil yang terletak dekat pembuluh darah [8]. Proses deteksi mikroaneurisma ditunjukan pada Gambar 8.

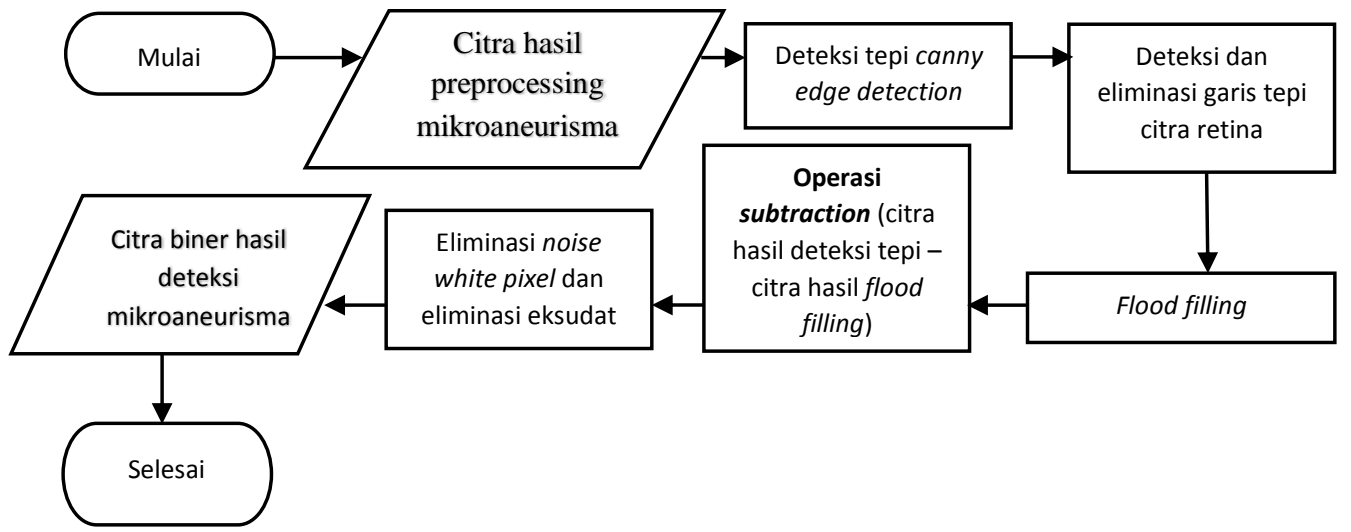

Gambar 8 Diagram alir proses deteksi mirkoaneurisma

\subsection{Rancangan Sistem Ekstraksi ciri}

Setelah melakukan proses deteksi eksudat, mikroaneurisma, dan pembuluh darah pada citra retina keudian melakukan proses ekstraksi ciri. Pada penelitian ini terdapat 2 proses ekstraksi ciri yaitu ekstraksi ciri area dari hasil deteksi dan ekstraksi ciri tekstur dengan metode GLCM (Gray Level Co-occurrence Matrix) orde 2. Pada ekstraksi ciri GLCM menggunakan 6 ciri statistik yaitu homogeneity, correlation, energy, invese difference moment, dan entropy. Citra yang akan dilakukan ekstraksi ciri GLCM terlebih dahulu diubah kedalam bentuk grayscale kemdian di lakukan perbaikan citra dengan metode CLAHE. Setelah itu citra tersebut di eliminasi optical disc nya. Eliminasi optical disc bertujuan untuk mengurangi kesalahan pada saat klasifikasi dikarenakan optical disc mempunyai tingkat kecerahan yang sama dengan eksudat [8]. Tahapan ekstraksi ciri dapat dilakukan dengan tahapan seperti Gambar 9. 


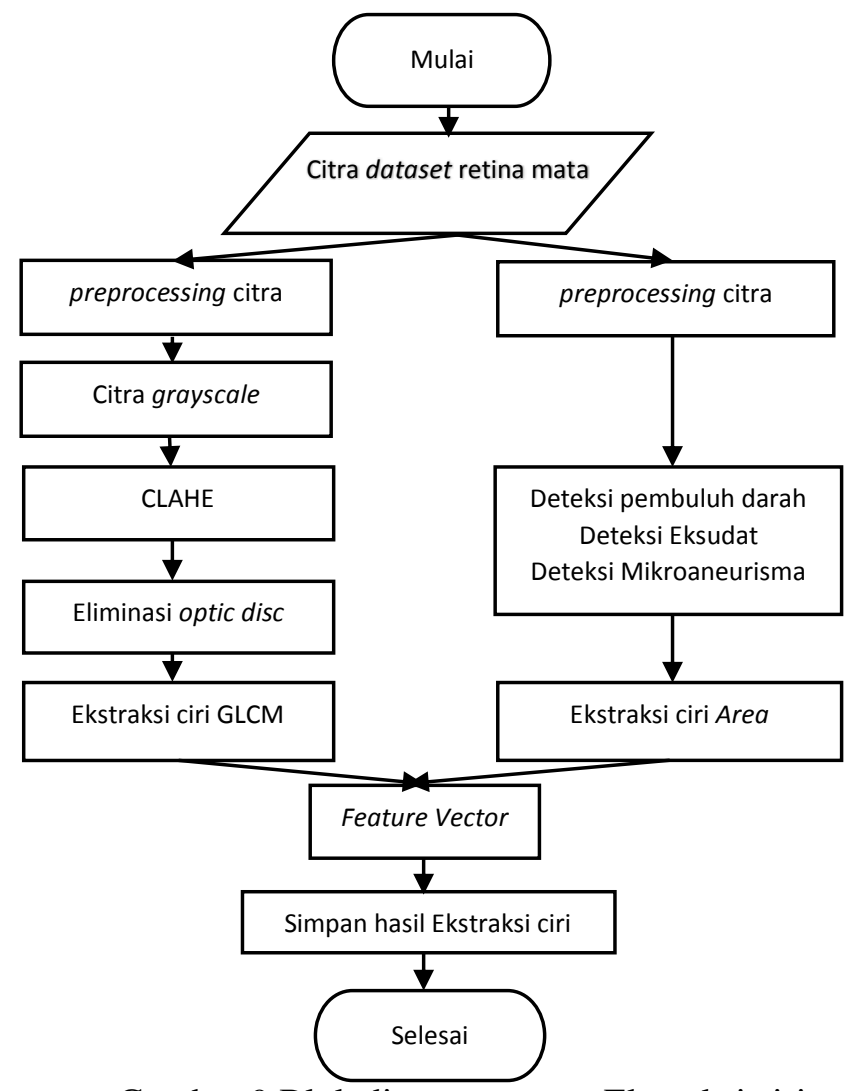

Gambar 9 Blok diagram proses Ekstraksi ciri

\subsection{Rancangan Sistem Klasifikasi}

Klasifikasi sistem ini mengunakan metode Support vector machine (SVM). Metode ini akan mengklasifikasikan empat fase retinopati diabetik (normal, mild NPDR, moderate NPDR, severe NPDR). Proses klasifikasi ditunjukan pada Gambar 10.

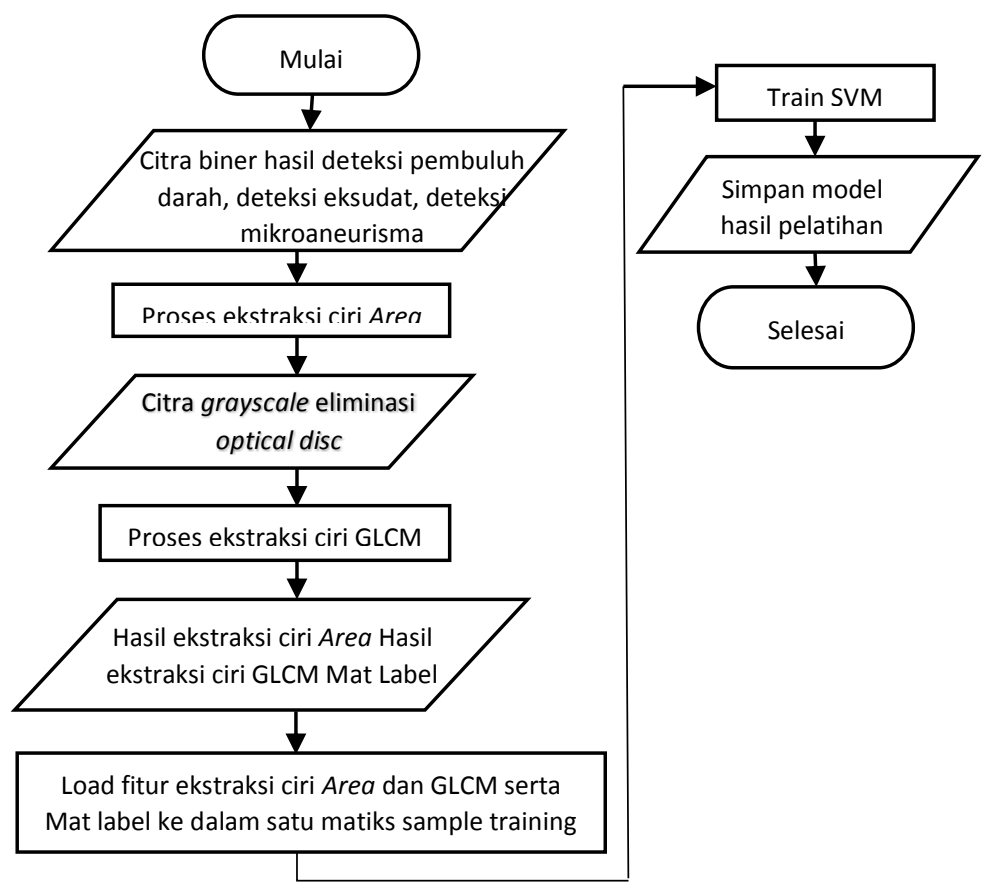

Gambar 10 Diagram alir proses klasifikasi tahap pelatihan 


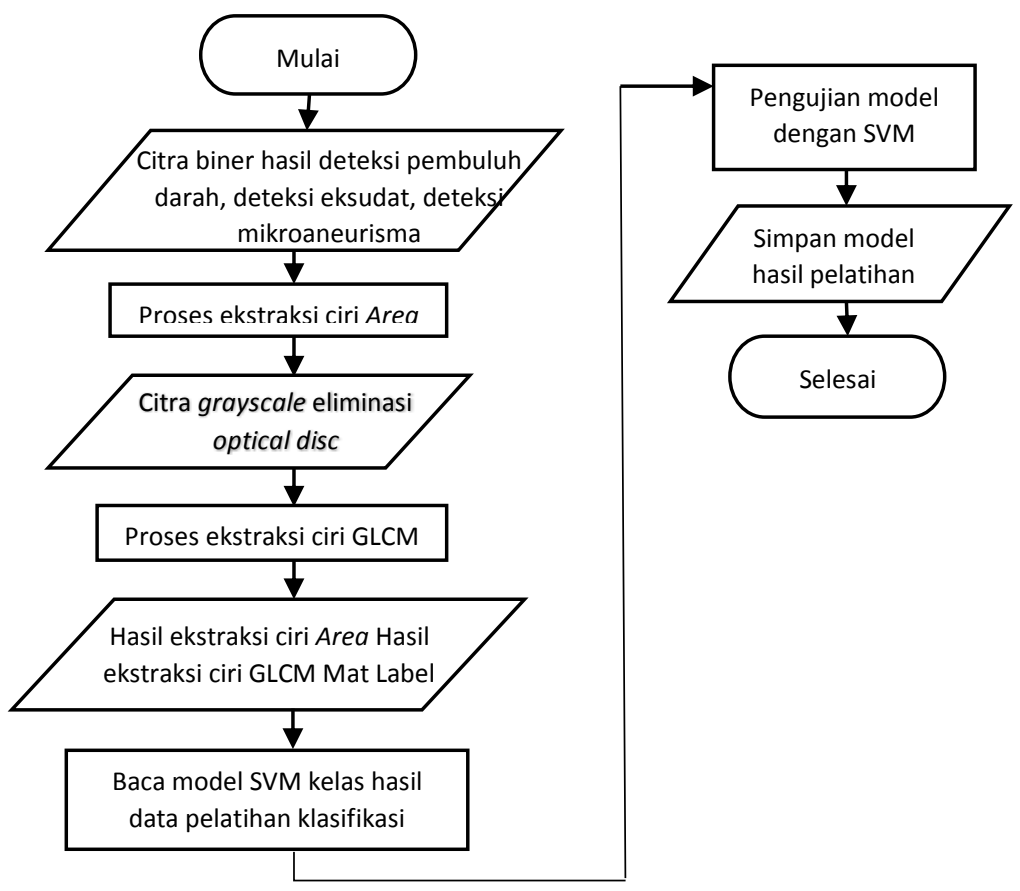

Gambar 11 Diagram alir proses klasifikasi tahap pengujian

Pada Gambar 10 merupakan tahap pelatihan dan Gambar 11 merupakan tahap pengujian. Pada tahap pelatihan nantinya akan menghasil suatu model yang akan dibandingkan pada tahap pengujian klasifikasi. Support Vector Machine (SVM) merupakan supervised learning dengan algoritma pembelajaran terkait yang menganalisis data dan mengenali pola yang digunakan untuk analisis klasifikasi dan regresi. SVM memetakan vektor input ke ruang vektor dimensi yang lebih tinggi dimana hyperplane optimal dibangun. Di antara banyak hyperplane, hanya ada satu hyperplane yang memaksimalkan jarak antara dirinya dan data vektor terdekat dari masing-masing kategori [9].

\subsection{Rancangan GUI}

GUI merupakan tampilan program yang dirancang sedemikian rupa sehingga dapat mempermudah user dalam menggunakan. Fungsi dari aplikasi berbasis GUI yang dibuat dengan menggunakan Matlab untuk proses deteksi dan proses klasifikasi tingkat keparahan retinopati diabetik. Rancangan GUI ditunjukan pada Gambar 12.

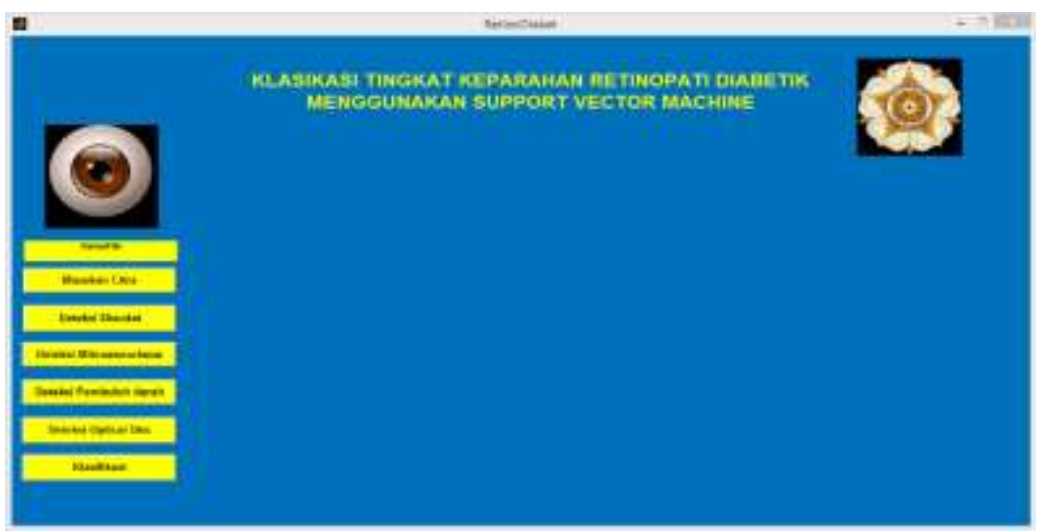

Gambar 12 Rancangan GUI

GUI ini dilengkapi dengan tombol push button untuk melakukan proses deteksi dan proses klasifikasi. Tombol proses deteksi terdiri dari deteksi pembuluh darah, eksudat, dan 
mikroaneurisma. Sedangkan untuk tombol klasifikasi terdapat 2 bagian yaitu klasifikasi single image dan klasifikasi citra jamak dengan keluaran berupa nilai akurasi dan tabel confusion matrix.

\section{HASIL DAN PEMBAHASAN}

Tujuan dari tahap pengujian untuk mengetahui seberapa baik kinerja sistem klasifikasi fase retinopati diabetik dengan metode Support Vetctor Machine. Pada penelitian ini menggunakan 1200 data citra dari database MESSIDOR (Methods to evaluate segmentation and indexing techniques ini the field of retinal opthamology).

\subsection{Proses Detesksi Citra}

Pada tahap deteksi citra pada penelitian ini bertujuan untuk mendeteksi keberadaan eksudat, pembuluh darah, dan mikroaneurisma. Sebelum memasuki tahap klasifikasi terlebih dahulu mendeteksi tanda-tanda yang muncul pada citra retina mata penderita retinopati diabetik seperti eksudat, pembuluh darah, dan mikroaneurisma. Proses deteksi citra menghasilkan citra deteksi berupa citra biner. Optical disc mempunyai tingkat kecerahan yang sama dengan eksudat maka saat proses deteksi eksudat dan proses ekstraksi ciri GLCM diperlukan mengeliminasi optical disc untuk mengurangi kesalahan klasifikasi. Setelah melakukan eliminasi optical disc dan garis tepi citra retina maka didapatkan citra hasil deteksi eksudat, pembuluh darah, dan mikroaneurisma seperti yang terlihat pada Gambar 13.

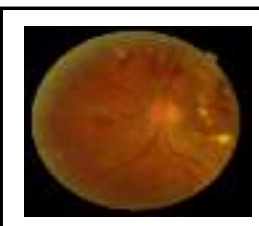

Citra original

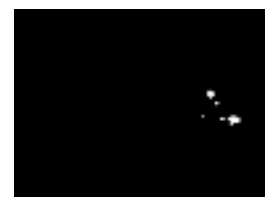

Eksudat

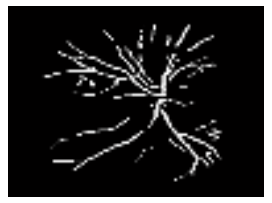

Pembuluh darah

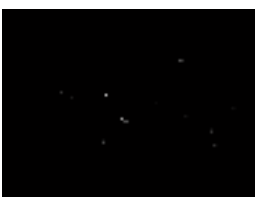

Mikroaneurisma

Gambar 13 Hasil proses deteksi citra

\subsection{Pelatihan Kasifikasi Fase Retinopati Diabetik}

Setelah melakaukan ekstraksi ciri menggunakan ekstraksi ciri area dari hasil deteksi dan ekstraksi ciri tekstur GLCM, kemudian hasil ekstraksi ciri di klasifikasi berdasarkan nilai support vector yang dihasilkan dari data training. Data training untuk klasifikasi pada penelitian berbentuk vektor dengan format file mat. Pemodelan SVM dengan tiga jenis kernel (Linear, RBF(Radial Basis Function), dan Polynomial) yang berbeda didapatkan dari sistem pelatihan fase retinopati diabetik. Kemudian hasil dari pemodelan digunakan untuk klasifikasi pada tahap pengujian.

\subsection{Pengujian Kasifikasi Fase Retinopati Diabetik}

Tahap pengujian penelitian yang pertama adalah melakukan perbandingan tiga kernel yang berbeda. Pengujian kernel menggunakan enam variasi data yang berbeda dengan tiga ekstraksi ciri area hasil deteksi dan empat arah serta enam ciri statistic GLCM. Hasil pengujian variasi data dan kernel dapat dilihat pada Tabel 1.

Tabel 1 Hasil Pengujian variasi data dan kernel

\begin{tabular}{|l|c|c|c|c|c|c|}
\hline No. & Data & \multicolumn{5}{|c|}{ Akurasi Kernel } \\
& training & & \multicolumn{5}{|c|}{ data testing } \\
\cline { 3 - 7 } & & Linear & RBF & $\begin{array}{c}\text { Polynomial } \\
\text { orde 1 }\end{array}$ & $\begin{array}{c}\text { Polynomial } \\
\text { orde 2 }\end{array}$ & $\begin{array}{c}\text { Polynomial } \\
\text { orde 3 }\end{array}$ \\
\hline 1. & $240 \times 60$ & $70,00 \%$ & $78,33 \%$ & $73,33 \%$ & $58,33 \%$ & $71,67 \%$ \\
\hline 2. & $560 \times 140$ & $42,14 \%$ & $50,00 \%$ & $40,00 \%$ & $35,71 \%$ & $43,57 \%$ \\
\hline 3. & $720 \times 180$ & $53,00 \%$ & $53,33 \%$ & $52,22 \%$ & $42,78 \%$ & $44,44 \%$ \\
\hline
\end{tabular}




\begin{tabular}{|l|c|c|c|c|c|c|}
\hline 4. & $960 \times 240$ & $60,00 \%$ & $60,42 \%$ & $60,00 \%$ & $56,67 \%$ & $56,25 \%$ \\
\hline
\end{tabular}

Pada pengujian variasi data dan kernel, variasi data nomor 2 sampai nomor 4 memiliki kelas yang tidak seimbang. Ketidak seimbangan kelas yang di akibatkan jumlah data kelas normal dan kelas severe NPDR lebih banyak dari pada kelas lain menyebabkan hasil klasifikasi cenderung berada pada kelas yang memiliki data paling banyak. Maka dari itu perlu dilakukan oversampling menggunakan SMOTE (Synthetic Minority Oversampling Technique) pada variasi data nomor 2 sampai nomor 4 . Hasil oversampling tersebut menghasilkan nilai akurasi terbaik pada variasi data nomor 3 dan 4 dengan kernel RBF sebesar 51,67\% dan 50,42\%. Kemudian diambil 3 variasi data yang menghasilkan akurasi terbaik pada kernel RBF yaitu variasi data nomor 1, 3, dan 4.

Pengujian dilanjutkan dengan melakukan $k$-fold cross validation pada ketiga variasi data tersebut untuk mendapatkan parameter $\mathrm{C}$ dan gamma yang optimal. Langkah pengujian selanjutnya melakukan klasifikasi SVM pada variasi satu arah GLCM untuk mendapatkan arah GLCM terbaik. Pengujian ini menggunakan parameter $\mathrm{C}$ dan gamma terbaik hasil dari pengujian $k$-fold cross validation dengan kernel RBF (Radial Basis Function). Hasil akurasi variasi satu arah GLCM ditunjukan pada Tabel 2.

Tabel 2 Hasil Pengujian variasi satu arah GLCM

\begin{tabular}{|c|c|c|c|c|c|c|}
\hline \multirow[t]{2}{*}{ No. } & \multirow[t]{2}{*}{$\begin{array}{l}\text { Data training } \\
\mathrm{x} \text { data testing }\end{array}$} & \multirow[t]{2}{*}{ Area } & \multicolumn{4}{|c|}{$\begin{array}{c}\text { Akurasi } \\
\text { GLCM } 1 \text { arah }\end{array}$} \\
\hline & & & $\mathbf{0}^{\circ}$ & $45^{\circ}$ & $90^{\circ}$ & $135^{\circ}$ \\
\hline 1. & $240 \times 60$ & 3 ciri Area & $90,00 \%$ & $91,67 \%$ & $90,00 \%$ & $89,19 \%$ \\
\hline 2. & $720 \times 180$ & 3 ciri Area & $55,55 \%$ & $56,11 \%$ & $51,11 \%$ & $50 \%$ \\
\hline 3. & $960 \times 240$ & 3 ciri Area & $55,55 \%$ & $56,25 \%$ & $44,58 \%$ & $46,25 \%$ \\
\hline
\end{tabular}

Pengujian variasi satu arah GLCM pada variasi data 240x60 menghasilkan akurasi terbaik pada arah $45^{\circ}$ dengan nilai akurasi sebesar $91,67 \%$. Pengujian pada 60 citra data testing menghasilkan confusion matrix seperti yang ditunjukan pada Tabel 3. Pada hasil confusion matrix 60 citra data testing terlihat kelas normal dan kelas severe NPDR dapat di klasifikasikan dengan baik.

\begin{tabular}{|c|c|c|c|c|}
\hline Peal Predict & Normal & Mild NPDR & $\begin{array}{c}\text { Moderate } \\
\text { NPDR }\end{array}$ & Severe NPDR \\
\hline Normal & 16 & 0 & 0 & 0 \\
\hline Mild NPDR & 1 & 11 & 2 & 0 \\
\hline Moderate NPDR & 1 & 1 & 12 & 0 \\
\hline Severe NPDR & 0 & 0 & 0 & 16 \\
\hline
\end{tabular}

Tabel 3 Hasil confusion matrix 60 citra retina mata

Evaluasi sistem untuk klasifikasi setiap fase retinopati menggunakan 3 persamaan yaitu persamaan (1) Accuracy, persamaan (2) Specificity, dan persamaan (3) Sensitivity. Pada pengujian digunakan beberapa parameter tingkat keberhasilan untuk menguji sistem dengan mengukur nilai akurasi (accuration), sensitivity (recall), dan kekhususan (specificity). Evaluasi kinerja ini menggunakan nilai TP (True positive), TN (True Negative), FN (False Negative) dan FP (False Positive).

Accuracy $=\frac{T P+T N}{T P+F N+T N+F P}$ 
Specificity $=\frac{T N}{T N+F P}$

(2)

Sensitivity $=\frac{T P}{T P+F N}$

Sistem klasifikasi fase retinopati diabetik dalam penelitian ini akan mengevaluasi setiap citra hasil deteksi dengan persamaan (1), persamaan (2), dan persamaan (3) dalam setiap fase retinopati diabetik yang diklasifikasikan. Hasil ini kemudian di rata-rata untuk mendapatkan kesimpulan nilai variasi accuracy, specificity, dan sensitivity dari 60 testing data pada Tabel 4 merupakan hasil evaluasi rata-rata klasifikasi fase retinopati diabetik.

Tabel 4 Hasil rata-rata klasifikiasi fase retinopati diabetik

\begin{tabular}{|l|c|c|c|c|c|}
\hline $\begin{array}{l}\text { Hasil klasifikasi } \\
\text { SVM (\%) }\end{array}$ & Normal & Mild NPDR & $\begin{array}{c}\text { Moderate } \\
\text { NPDR }\end{array}$ & $\begin{array}{c}\text { Severe } \\
\text { NPDR }\end{array}$ & Rata - rata \\
\hline Accuracy & $96,77 \%$ & $93,44 \%$ & $93,54 \%$ & $100 \%$ & $95,93 \%$ \\
\hline Specificity & $95,65 \%$ & $97,87 \%$ & $95,65 \%$ & $100 \%$ & $97,29 \%$ \\
\hline Sensitivity & $100 \%$ & $78,57 \%$ & $85,71 \%$ & $100 \%$ & $91,07 \%$ \\
\hline
\end{tabular}

Hasil rata-rata klasifikasi fase retinopati diabetik menunjukan variasi 240 data training dan 60 data testing lebih baik dibandingkan dengan variasi data yang lain dikarenakan pada variasi data 240x60 memiliki sedikit variasi kondisi citra yang mempengaruhi proses deteksi eksudat, mikroaneurisma, dan pembuluh darah.

\section{KESIMPULAN}

Berdasarkan hasil penelitian pemroses citra retina mata klasifikasi fase retinopati diabetik dan tahap pengujian sekaligus pembahasan yang telah dilakukan, maka dapat diambil beberapa kesimpulan bahwa kombinasi ekstraksi ciri area dari hasil deteksi pembuluh darah, eksudat, mikroaneurisma dengan 6 ciri ekstraksi fitur Gray Level Co-occurrence Matrix (Contrast, correlation, energy, entropy, homogeneity, inverse difference moment) pada arah $45^{\circ}$ telah berhasil mengklasifikasikan fase retinopati diabetik pada retina mata menjadi 4 kelas yaitu retina mata normal, retin mata mild NPDR, retina mata moderatr NPDR, dan retina mata severe NPDR.

Support Vector Machine dapat diterapkan untuk mengklasifikasikan fase retinopati diabetik. Performa sistem menggunakan kernel Radial Basis Function dengan parameter konstanta $\mathrm{C}=8$ dan nilai gamma $=0,1250$ menunjukan hasil yang lebih baik. Pengujian pada variasi data 240 data training dan 60 data testing mempunyai nilai rata-rata accuracy sebesar $95,93 \%$, nilai specificity sebesar 97,29\% dan nilai sensitivity sebesar 91,07

\section{SARAN}

Penelitian klasifikasi fase retinopati diabetik ini dapat masih terdapat banyak kekurangan. Maka dari itu dapat disempurnakan dengan dilakukan penelitian lebih lanjut untuk memperbaiki hasil sistem klasifikasi fase retinopati diabetik dalam penelitian ini seperti melakukan peningkatan pada proses deteksi eksudat, pembuluh darah, dan mikroaneurisma untuk mengurangi kesalahan deteksi sehingga dapat menghasilkan sistem yang lebih akurat. Selain itu dengan dapat menggunakan kombinasi atau metode yang lain untuk ekstraksi fitur citra retina retinopati diabetik sehingga dapat mengklasifikasikan dengan lebih akurat dalam membedakan fase retinopati diabetik. 


\section{DAFTAR PUSTAKA}

[1] Yuhelma, Y. Hasneli and F.A. Nauli, "Identifikasi Dan Analisis Komplikasi Makrovaskuler dan Mikrovaskuler pada Pasien Diabetes Mellitus," Universitas Riau, 2014 [Online]. Avaible: https://jom.unri.ac.id/index.php/JOMPSIK/article/view/8343/8012. [Accesed: 17-April-2017]

[2] American Diabetes Association, "Diagnosis and Classification of Diabetes Mellitus," Diabetes Care, vol. 36, Supplement 1, Jan. 2013 [Online]. Available: https://doi.org/10.2337/dc13-S067. [Accesed: 20-April-2017]

[3] I. M. Stratton, S.J. Aldington, D.J. Taylor, A.I. Adler, and P.A. Scanlon, "A simple Risk Stratification for Time to Development of Sight-Threatening Diabetic Retinopathy," Diabetes Care, vol. 36, p. 580, Mar. 2013 [Online]. Available: https://doi.org/10.2337/dc12-0625. [Accesed: 21-April-2017]

[4] M. Kuivalainen, "Retinal Image Analysis Using Machine Vision," M.S. thesis, Department of Information Technology., Lappeenranta University of Technology., Finlandia., M.B, 2005 .

[5] P. R. Singh and M. Dixit, "Histogram Equalization: A Strong Technique for Image Enhancement," IJSIP (International Journal of Signal Processing, Image Processing and Pattern Recognition, Vol.8, No.8, pp. 345-352, 2015 [Online]. Available: wWw.sersc.org/journals/IJSIP/vol8 no8/35.pdf. [Accesed: 10-May-2017]

[6] P. S. Venugopala, H. Sarojadevi, A. Ankitha, and N. Niranjan, "An Approach to Improve Canny Edge Detection Using Morphological Filters," IJCA (International Journal of Computer Application, Vol.116, No. 9, Apr. 2015 [Online]. Available: http://www.ijcaonline.org/archives/volume116/number9/20368-2575. [Accesed: 12-May2017]

[7] A. Elbalaoui, M. Fakir, K. Taifi, and A. Merbouha, "Automatic Detection of Blood Vessel in Retinal Images," International Conference Computer Graphics Imageing and Visualization, Vol.12, Issue.1, pp. 14-29, 2017 [Online]. Available: https://doi.org/10.4018/IJHISI.2017010102. [Accesed: 13-May-2017]

[8] R. Yefrenes and A. Harjoko, "Klasifikasi Fase Retinopati Diabetes Menggunakan Backpropagation Neural Network," IJEIS (Indonesian Journal of Electronics and Instrumentations Systems, Vol.1, No.2, 2011 [Online]. Available: https://jurnal.ugm.ac.id/ijeis/article/view/1966/1771. [Accesed: 21-May-2017]

[9] T. Ruba, and K. Ramalakshmi, "Identification and Segmentation of Exudates Using SVM Classifier," in International Conference on Innovations in Information Embedded and Comunication $\quad$ System, 2015 [Online]. Available: https://doi.org/10.1109/ICIIECS.2015.7193219. [Accesed: 3-July-2017]

[10] X. Zhang, G. Thibault, E. Decencière, B. Marcotegui, B. Laÿ, R. Danno, G. Cazuguel, G. Quellec, M. Lamard, P. Massin, A. Chabouis, Z. Victor, and A. Erginay, "Exudate Detection in Color Retinal Images for Mass Screening of Diabetic Retinopathy," Medical Image Analysis, 2014 [Online]. Available: http://dx.doi.org/10.1016/j.media.2014.05.004. [Accesed: 17-july-2017] 